\title{
Siew New Disease Reports \\ First report of Meloidogyne mali causing root galling to elm trees in the UK
}

\author{
T. Prior $^{1} *$, H. Tozer ${ }^{2}$, R. Yale ${ }^{3}$, E.P. Jones ${ }^{1}$, R. Lawson ${ }^{1}$, L. Jutson ${ }^{1}$, M. Correia ${ }^{1}$, J. Stubbs ${ }^{1}$, S. Hockland ${ }^{1}$ and G. Karssen $^{4}$ \\ ${ }^{1}$ Fera Science Ltd., National Agri-food Innovation Campus, Sand Hutton, York, YO41 1 LZ United Kingdom; ${ }^{2}$ Plant Health \\ and Seed Inspectorate, Animal and Plant Health Agency, National Agri-food Innovation Campus, Sand Hutton, York, YO41 \\ 1LZ, United Kingdom; ${ }^{3}$ Department for Environment, Food and Rural Affairs, National Agri-food Innovation Campus, Sand \\ Hutton, York, YO41 1LZ, United Kingdom; ${ }^{4}$ National Plant Protection Organisation, Geertjesweg 15, 6706 EA Wageningen, \\ The Netherlands
}

*E-mail: thomas.prior@fera.co.uk

Received: 05 Mar 2019. Published: 18 Mar 2019. Keywords: geographical record, root-knot nematode, Ulmus

In October 2018, infective juveniles of Meloidogyne mali were isolated from a soil sample taken from the rhizosphere of elm trees (Ulmus sp.) located at one site in southern England. This surveillance work was carried out by the Plant Health and Seed Inspectorate following recommendations outlined in the EPPO pest risk analysis for the apple root-knot nematode, M. mali (EPPO, 2017). Statutory sampling at the location was carried out in December 2018, with M. mali populations observed infesting the roots of elm trees at this and one additional site (Fig. 1). Host roots exhibited the typical large galls, with small cavities, associated with this species (Fig. 2). A number of elm trees at each site have died, likely due to Dutch Elm Disease (DED); it is possible that nematode infestation could weaken the tree, making it more susceptible to infection by other pathogens.

Morphological identification was done on formalin-fixed infective juveniles and perineal patterns of mature females dissected from root galls. Diagnosis was confirmed using molecular sequencing; DNA was extracted from 13 samples (Blood and Tissue Kit, Qiagen), and a COI gene fragment amplified and sequenced using primers JFB3-F (5'-TTTTTTGGGCATCCTGAGGTTTAT-3') (Bowles et al., 1992) and JB5-R (5 '-AGCACCTAAACTTAAAACATAATGAAAATG-3') (Derycke et al., 2005). All sequences (from two haplotypes) were deposited in GenBank (Accession Nos. MK520909- MK520921). Sequences were BLAST searched against the Q-Bank database (Bonants et al., 2013) and shared a $99-100 \%$ sequence identity to records of M. mali and to M. ulmi, a synonym of M. mali (Ahmed et al., 2013). No other species in the database had greater than $87 \%$ sequence identity (M. minor and others). The phylogenetic relationship of the samples relative to Q-Bank sequences is presented in Figure 3.

Nematode specimens (infective juveniles, adult males and perineal patterns of mature females) were preserved in triethanolamine formalin, added to a $5 \%$ glycerol solution and incubated at $40^{\circ} \mathrm{C}$ to slowly evaporate the water and process nematodes into anhydrous glycerol before being slide mounted. Material has been deposited as voucher specimens in the UK National Collection of Plant-Parasitic Nematodes (NCPPN; accession numbers FNCV11006 - 10). This collection forms part of the European Nematode Collection (http://www.nce.nu).

In the early 1980 's, European countries received potentially infested elm trees via The Netherlands, to conduct trials on DED resistance (Heybroek, 1983). The imported trees were removed and destroyed at the end of the trial period, however this polyphagous species persisted, infesting other elm trees at the site. This is a new geographical record of M. mali confirmed from the UK. This nematode is an EPPO A2 listed pest, having recently been recorded in The Netherlands associated with uprooting of elm trees during periods of adverse weather conditions (EPPO, 2017). This root-knot nematode species has also been reported from Italy and France.

\section{Acknowledgements}

The authors would like to thank Rebecca Mcllhiney for editorial review, and Chris Cunningham, Charlotte Davey, Amanda Dible, Maria del Mar Clemente Lujan, Joanna Maczko, Mark Oram and Paul Taylor for their assistance during statutory surveillance activities.

\section{References}

Bonants P, Edema M, Robert V, 2013. Q-bank, a database with information for identification of plant quarantine plant pest and diseases. EPPO Bulletin 43, 211-215. http://dx.doi.org/10.1111/epp.12030

Bowles J, Blair D, McManus DP, 1992. Genetic variants within the genus Echinococcus identified by mitochondrial DNA sequencing. Molecular and Biochemical Parasitology 54, 165-173.

http://dx.doi.org/10.1016/0166-6851(92)90109-W

Derycke S, Remerie T, Vierstraete A, Backeljau T, Vanfleteren J, Vincx M, Moens T, 2005. Mitochondrial DNA variation and cryptic speciation within the free-living marine nematode Pellioditis marina. Marine Ecology Progress Series 300, 91-103. http://dx.doi.org/10.3354/meps300091

EPPO, 2017. Pest risk analysis for Meloidogyne mali, apple root-knot nematode.https://gd.eppo.int/download/doc/1262_pra_exp_MELGMA.pdf (Accessed 5 March 2019).

Guindon S, Gascuel O, 2003. A simple, fast, and accurate algorithm to estimate large phylogenies by maximum likelihood. Systematic Biology $\mathbf{5 2}$, 696-704. http://dx.doi.org/10.1080/10635150390235520

Heybroek H, 1983. Resistant elms for Europe. Forestry Commission Bulletin , 108-113.

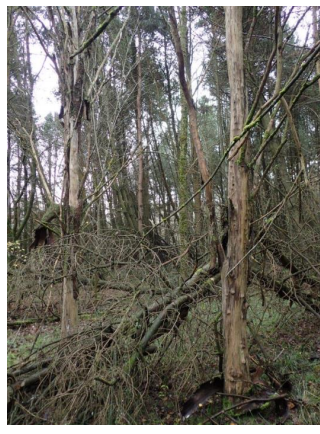

Figure 1

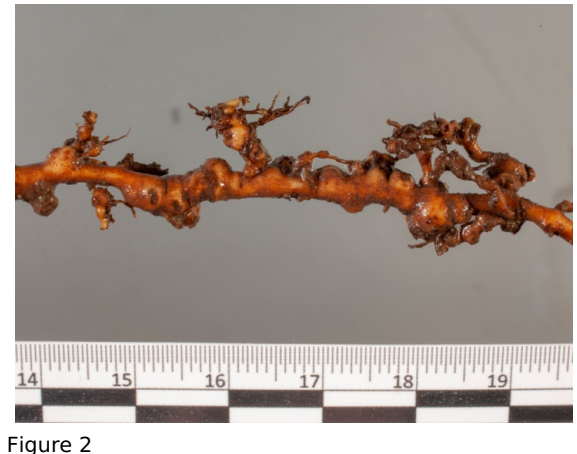

Figure 2

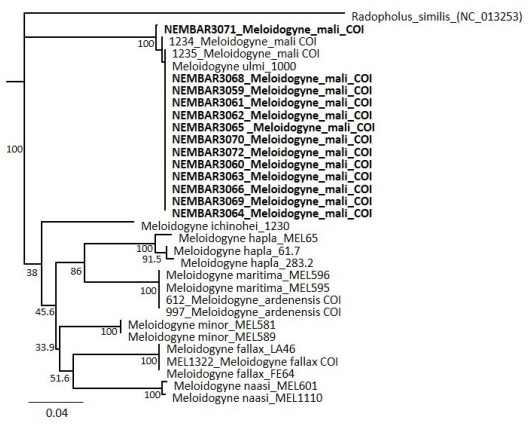

Figure 3

To cite this report: Prior T, Tozer H, Yale R, Jones EP, Lawson R, Jutson L, Correia M, Stubbs J, Hockland S, Karssen G, 2019. First report of Meloidogyne mali causing root galling to elm trees in the UK. New Disease Reports 39, 10. http://dx.doi.org/10.5197/j.2044-0588.2019.039.010 